\title{
A retrospective and prospective study of double malignancies in a tertiary care hospital in south India - a ten years' experience
}

\author{
S. Carbin Joseph ${ }^{1}$, C. Danny Darlington ${ }^{2}$, G. Fatima Shirly Anitha ${ }^{3}$
}

\author{
${ }^{1}$ Department of Surgery, Kannyakumari Government medical college, Kannyakumari District, Tamil Nadu, India \\ ${ }^{2}$ Department of Urology, Stanley medical college, Chennai, Tamil nadu, India \\ ${ }^{3}$ Department of Pediatrics, CSI Kalyani Hospital, Mylapore, Chennai, India
}

Received: 17 January 2016

Revised: 02 March 2016

Accepted: 17 March 2016

\section{*Correspondence:}

Dr. C. Danny Darlington,

E-mail: dannymbbs2009@yahoo.com

Copyright: () the author(s), publisher and licensee Medip Academy. This is an open-access article distributed under the terms of the Creative Commons Attribution Non-Commercial License, which permits unrestricted non-commercial use, distribution, and reproduction in any medium, provided the original work is properly cited.

\section{ABSTRACT}

Background: The occurrence of second malignancies in cancer survivors is not uncommon. Due to advances in diagnostic and therapeutic modalities, the survival of cancer patients has improved and the incidence of second malignancies is also on the rise. The second malignancy may be synchronous or metachronous. Though there are plenty of case reports on double malignancies, original studies are less. The present study aims to analyse the frequency, types of double malignancies and their effect on the morbidity and mortality of the patients.

Methods: This is a retrospective and prospective analysis of cancer patients done in a tertiary care hospital. All patients who presented with double malignancies from January 2004 to December 2014 were included. Retrospective data was obtained for cases from January 2004 to October 2011 and prospective data was obtained from November 2011 to December 2014. The study included 32 patients with double malignancies.

Results: Gynaecological malignancies were most common in our study, followed by head and neck and gastrointestinal malignancies. Most of the malignancies were synchronous (56.25\%). Double malignancies involving the head and neck, female reproductive tract, breast can be explained by common etiological factors like Human papillomma virus (HPV). Field cancerisation explains the synchronous cancers in Head and neck, upper aero digestive tract and reproductive tract.

Conclusions: This study emphasises the importance of screening cancer patients for other primary malignancies during initial evaluation as well as during follow up period, in addition to the metastatic workup. It also stresses that timely reduction of risk factors in cancer survivors can prevent further malignancies.

Keywords: Double malignancies, Field cancerisation, HPV, Metachronous malignancy, Synchronous malignancy

\section{INTRODUCTION}

The war against cancer which started long back is still continued by the oncologists and radiotherapists. Despite the various modalities of treatments offered, the cure rates are not much gratifying. Although this is the situation regarding a single malignancy, now a days we encounter patients with double and triple malignancies. As a result of improvement in medical facilities and thereby the survival of cancer patients, the incidence of double malignancies is on the rise. ${ }^{1}$ The second cancers not only add to the morbidity and mortality of the patients but also to the distress of the treating surgeon and hence there is a need to study the nature of these double malignancies. The objective of this study was to estimate the frequency of double malignancies among all the malignancy cases studied, to analyze the common types of malignancies that occur together in relation to the 
other systems of the body, to evaluate the effect of second malignancy on the morbidity and mortality of the patient, and to study the field effect in malignancies.

\section{METHODS}

This is a retrospective and prospective analysis of patients with malignancies done in a tertiary government medical college hospital involving the departments of general surgery, medical oncology, radiotherapy, and gynecology. All patients who presented with double malignancies from January 2004 to December 2014 (10 years) were included in the study. Retrospective data was obtained for cases from January 2004 to October 2011 and prospective data was obtained for patients who presented between November 2011 and December 2014. During the study period of ten years, we had a total of 23003 malignancy cases; out of which only 32 patients had double malignancies. All these 32 patients had accurate histopathological reports and were considered for the analysis. Some patients were followed up, while others lost follow up due to poor survival rates. Informed consent was obtained from all individual participants included in the study. Additional informed consent was obtained from all individual participants for whom identifying information is included in this article. The study was approved by the institutions' ethical committee.

\section{Inclusion criteria}

- $\quad$ Presence of at least two malignancies

- Histologically confirmed tumours

- Different histology in the two locations

\section{Exclusion criteria}

- Patients without proper histopathological reports and those in whom the second tumour was suspected to be metastasis from the first.

The selected patients were subjected to detailed clinical examination and were evaluated by biochemical, hematological investigations, FNAC (Fine Needle Aspiration Cytology), biopsy, imaging studies and endoscopy as needed. The interval of time to distinguish a metachronous from synchronous lesion was taken as six months.

\section{RESULTS}

In the present study, the youngest patient with double malignancies was 23 years and the oldest was 75 years of age. The mean age of all the patients with double malignancies studied was 48.21 years. $40.60 \%$ were males and $59.40 \%$ were females. One patient with advanced carcinoma stomach and carcinoma of the urinary bladder expired during the study period.

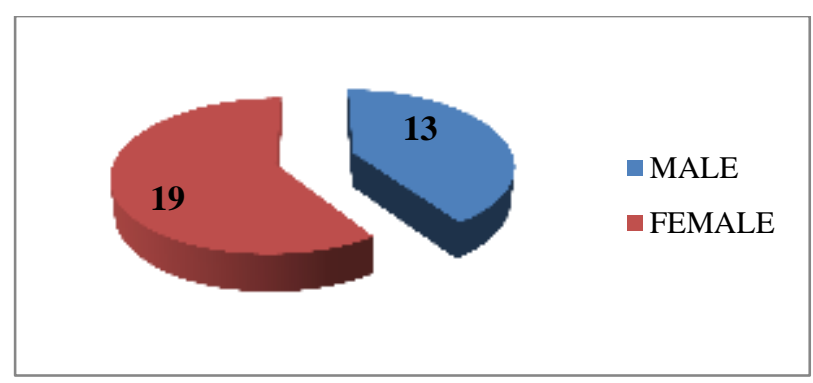

Figure 1: Gender distribution.

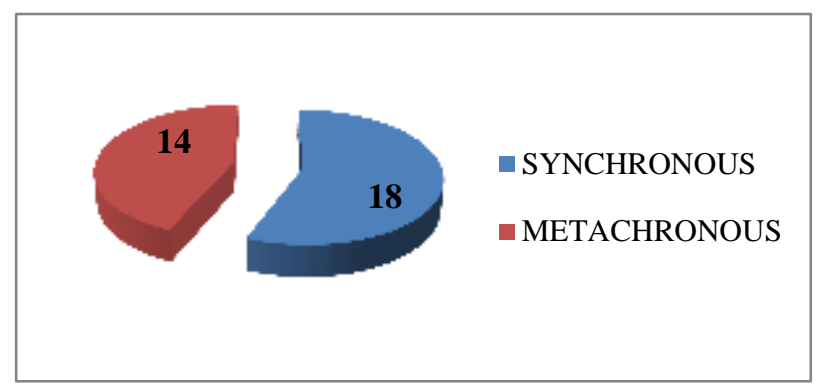

Figure 2: Synchronous versus metachronous malignancies.

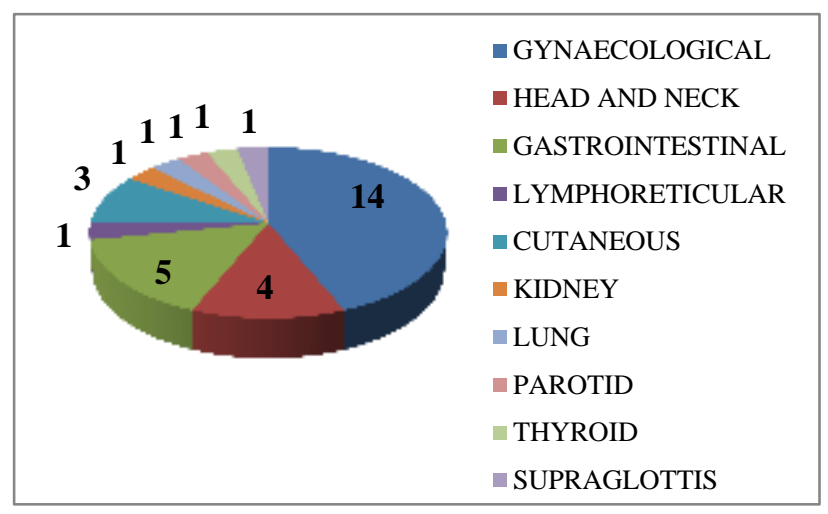

Figure 3: First malignancies distribution.

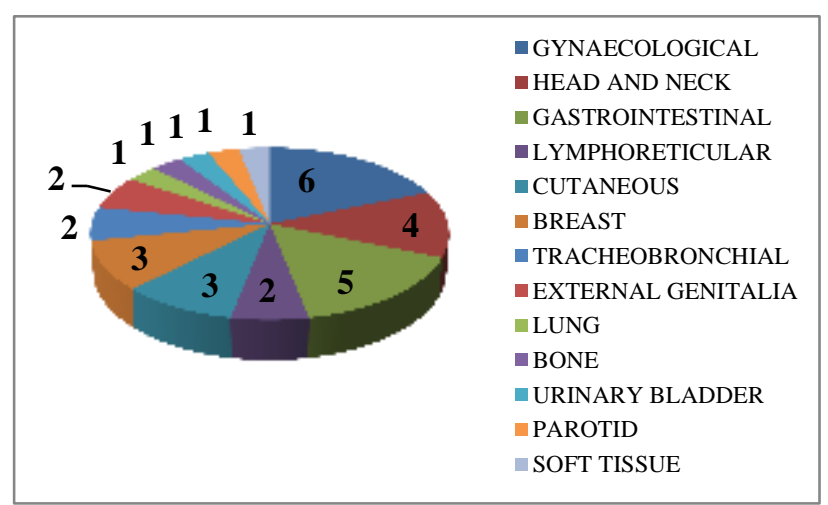

Figure 4: Second malignancies distribution. 
Table 1: Details of the patients included in the study.

\begin{tabular}{|c|c|c|c|c|c|c|c|}
\hline $\begin{array}{l}\text { Age } \\
\text { Yrs }\end{array}$ & Gender & Cancer 1 & Treatment & Cancer 2 & Treatment & Interval & $\begin{array}{l}\text { Other } \\
\text { features }\end{array}$ \\
\hline 45 & Female & $\begin{array}{l}\text { Cervix- } \\
\text { Squamous cell } \\
\text { carcinoma }\end{array}$ & Surgery & $\begin{array}{l}\text { Ovary } \\
\text { Papillary serous } \\
\text { adenocarcinoma }\end{array}$ & chemotherapy & Synchronous & $\begin{array}{l}\text { Gravida } 7, \\
\text { married for } 15 \\
\text { years }\end{array}$ \\
\hline 29 & Female & $\begin{array}{l}\text { Cervix- } \\
\text { Squamous cell } \\
\text { carcinoma }\end{array}$ & Radiotherapy & $\begin{array}{l}\text { Ovary } \\
\text { adenocarcinoma }\end{array}$ & $\begin{array}{l}\text { Surgery and } \\
\text { chemotherapy }\end{array}$ & $\begin{array}{l}\text { Metachronous, } \\
\text { after } 2 \text { years }\end{array}$ & $\begin{array}{l}\text { Post } \\
\text { Radiotherapy, } \\
\text { married for } 12 \\
\text { years }\end{array}$ \\
\hline 48 & Female & $\begin{array}{l}\text { Cervix-Adeno } \\
\text { carcinoma }\end{array}$ & Surgery & $\begin{array}{l}\text { Ovary-mucinous } \\
\text { adenocarcinoma }\end{array}$ & $\begin{array}{l}\text { Surgery and } \\
\text { chemotherapy }\end{array}$ & Synchronous & \\
\hline 48 & Female & $\begin{array}{l}\text { Cervix- } \\
\text { Squamous cell } \\
\text { carcinoma }\end{array}$ & surgery & $\begin{array}{l}\text { Ovary- papillary } \\
\text { cyst } \\
\text { adenocarcinoma }\end{array}$ & chemotherapy & Synchronous & $\begin{array}{l}\text { Gravida } 5, \\
\text { married for } 30 \\
\text { years }\end{array}$ \\
\hline 32 & Female & $\begin{array}{l}\text { Cervix } \\
\text { Squamous cell } \\
\text { carcinoma }\end{array}$ & Radiotherapy & $\begin{array}{l}\text { Bilateral Breast - } \\
\text { Infitrating ductal } \\
\text { carcinoma }\end{array}$ & $\begin{array}{l}\text { Surgery and } \\
\text { chemotherapy }\end{array}$ & Synchronous & \\
\hline 41 & Female & $\begin{array}{l}\text { Cervix- } \\
\text { Squamous cell } \\
\text { carcinoma }\end{array}$ & $\begin{array}{l}\text { Surgery and } \\
\text { Radiotherapy }\end{array}$ & $\begin{array}{l}\text { Breast- Infiltrating } \\
\text { ductal carcinoma }\end{array}$ & Surgery & $\begin{array}{l}\text { Metachronous } \\
\text { - } 2 \text { years }\end{array}$ & \\
\hline 39 & Female & $\begin{array}{l}\text { Cervix- } \\
\text { Squamous cell } \\
\text { carcinoma }\end{array}$ & Surgery & $\begin{array}{l}\text { Labium major- } \\
\text { Squamous cell } \\
\text { carcinoma }\end{array}$ & Surgery & Synchronous & \\
\hline 65 & Female & $\begin{array}{l}\text { Cervix- } \\
\text { Squamous cell } \\
\text { carcinoma }\end{array}$ & Radiotherapy & $\begin{array}{l}\text { Rib- } \\
\text { Chondrosarcoma }\end{array}$ & Surgery & Synchronous & \\
\hline 25 & Female & $\begin{array}{l}\text { Uterus- } \\
\text { Gestational } \\
\text { trophoblastic } \\
\text { neoplasia }\end{array}$ & Surgery & $\begin{array}{l}\text { Ovary- Endodermal } \\
\text { sinus tumour }+ \\
\text { Dysgerminoma }\end{array}$ & $\begin{array}{l}\text { Surgery and } \\
\text { chemotherapy }\end{array}$ & Synchronous & $\begin{array}{l}\text { Gravida4, } \\
\text { Live 1, } \\
\text { Abortion 3, } \\
\text { Married } 3 \\
\text { years }\end{array}$ \\
\hline 45 & Female & $\begin{array}{l}\text { Uterus- } \\
\text { leiomyo } \\
\text { sarcoma }\end{array}$ & surgery & $\begin{array}{l}\text { Fallopian tube- } \\
\text { Adenocarcinoma }\end{array}$ & $\begin{array}{l}\text { Surgery and } \\
\text { chemotherapy }\end{array}$ & Synchronous & $\begin{array}{l}\text { Gravida } 6, \\
\text { Married for } \\
15 \text { years }\end{array}$ \\
\hline 42 & Female & $\begin{array}{l}\text { Uterus Adeno- } \\
\text { carcinoma }\end{array}$ & $\begin{array}{l}\text { Surgery and } \\
\text { radiotherapy }\end{array}$ & $\begin{array}{l}\text { Trachea- } \\
\text { Adenocarcinoma }\end{array}$ & $\begin{array}{l}\text { Chemotherap } \\
\text { y }\end{array}$ & $\begin{array}{l}\text { Metachronous } \\
-3 \text { years }\end{array}$ & Post radiation \\
\hline 28 & Female & $\begin{array}{l}\text { Uterus- Adeno } \\
\text { carcinoma }\end{array}$ & $\begin{array}{l}\text { Surgery and } \\
\text { Radiotherapy }\end{array}$ & $\begin{array}{l}\text { Bronchus- } \\
\text { Adenocarcinoma }\end{array}$ & $\begin{array}{l}\text { Chemotherap } \\
\text { y }\end{array}$ & $\begin{array}{l}\text { Metachronous } \\
-3 \text { years }\end{array}$ & $\begin{array}{l}\text { Post } \\
\text { Radiation }\end{array}$ \\
\hline 55 & Female & $\begin{array}{l}\text { Ovary- } \\
\text { Papillary } \\
\text { serous adeno } \\
\text { carcinoma }\end{array}$ & $\begin{array}{l}\text { Surgery, } \\
\text { Chemotherap } \\
\text { y }\end{array}$ & $\begin{array}{l}\text { Breast- Infiltrating } \\
\text { ductal carcinoma }\end{array}$ & Surgery & Synchronous & $\begin{array}{l}\text { Gravida } 6, \\
\text { Married for } \\
37 \text { years }\end{array}$ \\
\hline 70 & Male & $\begin{array}{l}\text { Tongue- } \\
\text { Squamous cell } \\
\text { carcinoma }\end{array}$ & Radiotherapy & $\begin{array}{l}\text { Lip- Squamous cell } \\
\text { carcinoma }\end{array}$ & Surgery & Synchronous & $\begin{array}{l}\text { Tobacco } \\
\text { chewer for } 40 \\
\text { years }\end{array}$ \\
\hline 63 & Male & $\begin{array}{l}\text { Foot- } \\
\text { Squamous cell } \\
\text { carcinoma }\end{array}$ & $\begin{array}{l}\text { Surgery- } \\
\text { amputation }\end{array}$ & $\begin{array}{l}\text { Oral cavity- } \\
\text { Squamous cell } \\
\text { carcinoma }\end{array}$ & Surgery & $\begin{array}{l}\text { Metachronous } \\
-10 \text { years }\end{array}$ & $\begin{array}{l}\text { Smoker -20 } \\
\text { years }\end{array}$ \\
\hline 50 & Male & $\begin{array}{l}\text { Cheek- } \\
\text { Squamous cell } \\
\text { carcinoma }\end{array}$ & Radiotherapy & $\begin{array}{l}\text { Esophagus Upper } \\
\text { 1/3rd- Squamous } \\
\text { cell carcinoma }\end{array}$ & $\begin{array}{l}\text { Palliative } \\
\text { surgery }\end{array}$ & $\begin{array}{l}\text { Metachronous } \\
-9 \text { years }\end{array}$ & $\begin{array}{l}\text { Smoker for } 25 \\
\text { years, post } \\
\text { Radiation }\end{array}$ \\
\hline 60 & Male & $\begin{array}{l}\text { Cheek- } \\
\text { Squamous cell } \\
\text { carcinoma }\end{array}$ & surgery & $\begin{array}{l}\text { Lung- Squamous } \\
\text { cell carcinoma }\end{array}$ & Radiotherapy & Synchronous & $\begin{array}{l}\text { Smoker for } 30 \\
\text { years }\end{array}$ \\
\hline
\end{tabular}




\begin{tabular}{|c|c|c|c|c|c|c|c|}
\hline 49 & Male & $\begin{array}{l}\text { Cheek- } \\
\text { Squamous cell } \\
\text { carcinoma }\end{array}$ & Radiotherapy & $\begin{array}{l}\text { Penis- Squamous } \\
\text { cell carcinoma }\end{array}$ & Surgery & $\begin{array}{l}\text { Synchronous- } \\
3 \text { months }\end{array}$ & $\begin{array}{l}\text { Tobacco } \\
\text { chewer for } 25 \\
\text { years, Post } \\
\text { radiation }\end{array}$ \\
\hline 55 & Female & $\begin{array}{l}\text { Rectum- Adeno } \\
\text { carcinoma }\end{array}$ & $\begin{array}{l}\text { Surgery and } \\
\text { chemotherapy }\end{array}$ & $\begin{array}{l}\text { Cheek- Squamous } \\
\text { cell carcinoma }\end{array}$ & Radiotherapy & $\begin{array}{l}\text { Metachronous } \\
-8 \text { months }\end{array}$ & $\begin{array}{l}\text { Post } \\
\text { chemotherapy }\end{array}$ \\
\hline 52 & Female & $\begin{array}{l}\text { Cheek- } \\
\text { Squamous cell } \\
\text { carcinoma }\end{array}$ & Radiotherapy & $\begin{array}{l}\text { Thyroid- Follicular } \\
\text { carcinoma }\end{array}$ & Surgery & Synchronous & $\begin{array}{l}\text { Tobacco } \\
\text { chewer for } 20 \\
\text { years, post } \\
\text { radiation }\end{array}$ \\
\hline 55 & Male & $\begin{array}{l}\text { Parotid- Adeno } \\
\text { carcinoma }\end{array}$ & Surgery & $\begin{array}{l}\text { Back- soft tissue } \\
\text { sarcoma }\end{array}$ & surgery & Synchronous & \\
\hline 63 & Male & $\begin{array}{l}\text { Supraglottis- } \\
\text { Squamous cell } \\
\text { carcinoma }\end{array}$ & Radiotherapy & $\begin{array}{l}\text { Parotid- } \\
\text { Adenocarcinoma }\end{array}$ & $\begin{array}{l}\text { Inoperable- } \\
\text { Palliation }\end{array}$ & $\begin{array}{l}\text { Metachronous } \\
-7 \text { years }\end{array}$ & Post radiation \\
\hline 40 & Female & $\begin{array}{l}\text { Colon- Adeno } \\
\text { carcinoma }\end{array}$ & $\begin{array}{l}\text { Surgery and } \\
\text { chemotherapy }\end{array}$ & $\begin{array}{l}\text { Esophagus- } \\
\text { Squamous cell } \\
\text { carcinoma }\end{array}$ & Surgery & $\begin{array}{l}\text { Metachronous } \\
-2 \text { years }\end{array}$ & $\begin{array}{l}\text { Post } \\
\text { chemotherapy }\end{array}$ \\
\hline 42 & Male & $\begin{array}{l}\text { Caecum-Adeno } \\
\text { carcinoma }\end{array}$ & $\begin{array}{l}\text { Surgery and } \\
\text { chemotherapy }\end{array}$ & $\begin{array}{l}\text { Stomach- } \\
\text { Adenocarcinoma }\end{array}$ & $\begin{array}{l}\text { Inoperable- } \\
\text { Palliation }\end{array}$ & $\begin{array}{l}\text { Metachronous } \\
-10 \text { years }\end{array}$ & $\begin{array}{l}\text { Smoker and } \\
\text { alcoholic for } \\
15 \text { years, post } \\
\text { chemotherapy }\end{array}$ \\
\hline 45 & Female & $\begin{array}{l}\text { Stomach- } \\
\text { Adeno } \\
\text { carcinoma }\end{array}$ & $\begin{array}{l}\text { Advanced- } \\
\text { inoperable }\end{array}$ & $\begin{array}{l}\text { Urinary bladder- } \\
\text { Transitional cell } \\
\text { carcinoma }\end{array}$ & Expired & Synchronous & $\begin{array}{l}\text { Tobacco } \\
\text { chewer and } \\
\text { smoker for } 15 \\
\text { years }\end{array}$ \\
\hline 39 & Male & $\begin{array}{l}\text { Periampullary- } \\
\text { Adeno } \\
\text { carcinoma }\end{array}$ & $\begin{array}{l}\text { Advanced- } \\
\text { inoperable }\end{array}$ & $\begin{array}{l}\text { Melanoma- nodular } \\
\text { type }\end{array}$ & Palliative & Synchronous & $\begin{array}{l}\text { Had cerebral } \\
\text { metastases }\end{array}$ \\
\hline 75 & Female & $\begin{array}{l}\text { Fallopian tube- } \\
\text { Adeno } \\
\text { carcinoma }\end{array}$ & $\begin{array}{l}\text { Surgery and } \\
\text { chemotherapy }\end{array}$ & $\begin{array}{l}\text { Small bowel -Non } \\
\text { Hodgkins } \\
\text { Lymphoma }\end{array}$ & $\begin{array}{l}\text { Surgery and } \\
\text { chemotherapy }\end{array}$ & $\begin{array}{l}\text { Metachronous } \\
-3 \text { years }\end{array}$ & $\begin{array}{l}\text { Post } \\
\text { chemotherapy }\end{array}$ \\
\hline 54 & Male & $\begin{array}{l}\text { Lung- } \\
\text { Squamous cell } \\
\text { carcinoma }\end{array}$ & Radiotherapy & $\begin{array}{l}\text { Skull- Multiple } \\
\text { myeloma }\end{array}$ & $\begin{array}{l}\text { Chemotherap } \\
\text { y }\end{array}$ & Synchronous & \\
\hline 55 & Male & $\begin{array}{l}\text { Kidney- Adeno } \\
\text { carcinoma }\end{array}$ & $\begin{array}{l}\text { Surgery } \\
\text { (Radical } \\
\text { Nephrectomy) } \\
\text { Chemotherap- } \\
\text { y }\end{array}$ & $\begin{array}{l}\text { Generalised nodal- } \\
\text { Non hodgkins } \\
\text { lymphoma }\end{array}$ & $\begin{array}{l}\text { Chemotherap } \\
\mathrm{y}\end{array}$ & $\begin{array}{l}\text { Metachronous } \\
-10 \text { years }\end{array}$ & $\begin{array}{l}\text { Post } \\
\text { chemotherapy }\end{array}$ \\
\hline 34 & Male & $\begin{array}{l}\text { Cervical nodes- } \\
\text { Hodgkins } \\
\text { Lymphoma }\end{array}$ & Radiotherapy & $\begin{array}{l}\text { Esophagus upper } \\
1 / 3^{\text {rd }}-\text { Squamous } \\
\text { cell carcinoma }\end{array}$ & $\begin{array}{l}\text { Palliative } \\
\text { management }\end{array}$ & $\begin{array}{l}\text { Metachronous } \\
-14 \text { years }\end{array}$ & Post radiation \\
\hline 30 & Male & $\begin{array}{l}\text { Skin- } \\
\text { Melanoma }\end{array}$ & $\begin{array}{l}\text { Advanced- } \\
\text { only } \\
\text { chemotherapy }\end{array}$ & $\begin{array}{l}\text { Thigh- Squamous } \\
\text { cell carcinoma }\end{array}$ & $\begin{array}{l}\text { Advanced- } \\
\text { Palliative } \\
\text { management }\end{array}$ & Synchronous & $\begin{array}{l}\text { Known case } \\
\text { of } \\
\text { Oculocutaneo } \\
\text { us Albinism }\end{array}$ \\
\hline 23 & Female & $\begin{array}{l}\text { Inner canthus } \\
\text { of eye-Basal } \\
\text { cell carcinoma }\end{array}$ & Surgery & $\begin{array}{l}\text { Left eyelid- } \\
\text { Squamous cell } \\
\text { carcinoma }\end{array}$ & Surgery & $\begin{array}{l}\text { Metachronous } \\
-3 \text { years }\end{array}$ & $\begin{array}{l}\text { Known case } \\
\text { of Xeroderma } \\
\text { Pigmentosum }\end{array}$ \\
\hline
\end{tabular}

Among the double malignancies, 56.25\% were synchronous malignancies and $43.75 \%$ were metachronous. Metachronous malignancies occurred in the study population as early as eight months to as late as 14 years with a mean interval of 5.2 years between the two malignancies.
Gynaecological malignancies were the most commonly observed malignancies in the study group. Gastrointestinal malignancies were the second most common followed by head and neck malignancies. Around $28.10 \%$ of malignancies occurred following radiotherapy and $12.50 \%$ occurred following chemotherapy. 


\section{DISCUSSION}

The discussion about the cases in the present study can be simplified by classifying the cases into following groups:

- Gynaecological malignancies

- Head and Neck malignancies

- Gastro-intestinal malignancies

- Lymphoreticular malignancies

- Cutaneous malignancies

\section{Gynaecological malignancies}

Double malignancies of the female reproductive tract although rare, were the most common group observed in our study. According to one theory, the epithelia of cervix, uterus, fallopian tubes, ovaries and peritoneal surfaces simultaneously respond to a carcinogen. ${ }^{2}$ Shared hormonal receptors may also be responsible for the development of multiple primary malignancies in the female reproductive tract. The most common combination reported includes endometrial carcinoma and ovarian malignancies. ${ }^{3}$ Cervical malignancies coexisting with ovarian malignancies are very rare. Only two cases of squamous cell carcinoma of cervix and ovarian malignancies have been reported in literature. ${ }^{4,5}$ In our study there were four cases of co existent Squamous cell carcinoma of cervix and carcinoma ovary, which is a very rare finding (Table 1, Cases 1-4). In Case no. 2, the ovarian malignancy was metachronous occurring 2 years after radiotherapy. But in a report by Boice et al radiotherapy for carcinoma cervix was not found to increase the risk of secondary ovarian malignancies. ${ }^{6}$

Cases no.5 and 6, represent two cases of squamous cell carcinoma of cervix with carcinoma breast. Lonardo D et al were the first to propose the relationship between human papilloma virus (HPV) and carcinoma breast. In another study conducted in Japan, HPV-16 genomes were identified in breast neoplastic tissues and axillary lymph nodes using PCR (polymerase chain reaction) method. ${ }^{7}$ Widschwendter et al identified HPV 16 genome in breast cancer patients with past history of carcinoma cervix. ${ }^{9}$ HPV associated carcinoma breast tends to occur at younger age groups, with sexual activity being a risk factor. Both the cases in the present study are of young age group (32 and 41 years).Thus the above two cases can be assumed as having HPV as the common etiological factor.

HPV has also been implicated in malignancies of oral cavity, vulva, vagina, rectum, melanoma, bladder. ${ }^{10} \mathrm{HPV}$ $16,31,33$ are identified in vulvar malignant lesions. ${ }^{11}$ Thus HPV could be the shared etiological agent in Case no. 7 , with synchronous carcinoma cervix and labium majora.

Chondrosarcoma has been reported to occur after radiotherapy for testicular malignancy. ${ }^{12}$ No case has been reported so far with synchronous carcinoma of the cervix and chondrosarcoma of the rib. Hence, Case no. 8, (Figure 5) is the first case reported of synchronous squamous cell carcinoma cervix and rib chondrosarcoma.

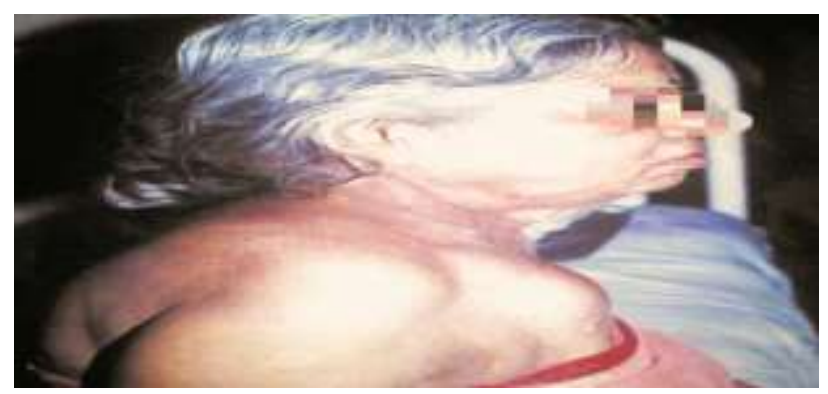

Figure 5: (Case no. 8) - Synchronous Rib chondrosarcoma in a 65 year old woman with carcinoma cervix.

Cases no. 9, a 25 years old woman with three abortions, had synchronous uterine gestational trophoblastic neoplasm and ovarian endodermal sinus tumor with dysgerminoma. Case no.10, is a synchronous uterine leiomyosarcoma with fallopian tube adenocarcinoma. Case no. 11 and 12, are tracheobronchial adenocarcinomas presenting 3 years after treatment of uterine adenocarcinoma. All these four cases are extremely rare and have never been reported so far. Hence our study forms the first report of such cases of double malignancies.

Case no. 14, a case of synchronous papillary serous adenocarcinoma of ovary and infiltrating ductal carcinoma of breast, may be secondary to BRCA1/2 mutations. But synchronous carcinoma of the ovary and breast is very rare .Only two cases have been reported before. $^{13-15}$

\section{Head and neck malignancies}

Case no. 14, represents a chronic tobacco chewer, with synchronous carcinoma of posterior $1 / 3^{\text {rd }}$ of tongue and the lower lip. Other than tobacco, HPV can be a factor in etiopathogenesis of both the malignancies as suggested by a study by Jain et al. ${ }^{16}$ Another possible explanation is the "field effect" which occurs in head and neck tumours and upper autodigestive tract. ${ }^{17}$ Case no. 15, metachronous carcinoma oral cavity 10 years after amputation for squamous cell carcinoma of the foot, could also be HPV induced. But no such double malignancy has been reported so far.

Case no. 16, was a patient, a chronic smoker, with synchronous carcinoma of cheek and squamous cell carcinoma of esophagus. This combination has been reported in multiple studies. ${ }^{18}$ The risk factors include alcoholism, smoking, male gender. Field cancerisation is a plausible explanation for this scenario. 
Case no. 17, was a case of carcinoma cheek with synchronous squamous cell carcinoma of the lung. Lung malignancy with oral cavity secondary deposits and metachronous oral cavity carcinoma occurring after carcinoma lung has been reported. But synchronous cancers in these two locations have not been reported. ${ }^{19-20}$

Case no. 18, (Figure 6) presented with squamous cell carcinoma cheek, for which he received radiotherapy. After 3 months he presented again with a synchronous carcinoma of penis with bilateral inguinal nodal metastases. Such synchronous malignancies in these two organs have not been reported in literature. A probable role of HPV in the etiology of these two malignancies may be evident.

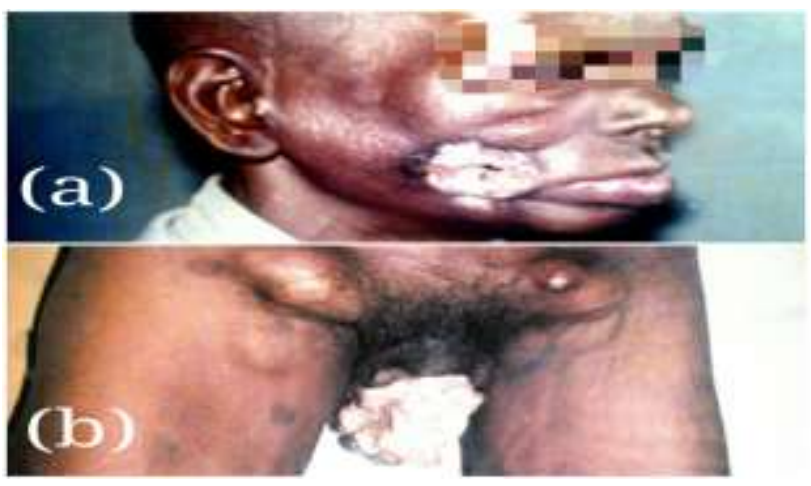

Figure 6: (Case no. 18) - (a) Carcinoma Cheek which was treated with radiotherapy, (b) synchronous carcinoma of penis with bilateral inguinal secondaries in the same patient.

Case no. 19, is a woman with metachronous squamous cell carcinoma of the cheek occurring 8 months after surgery for adenocarcinoma of the rectum. This is the first instance in literature of such double malignancies.

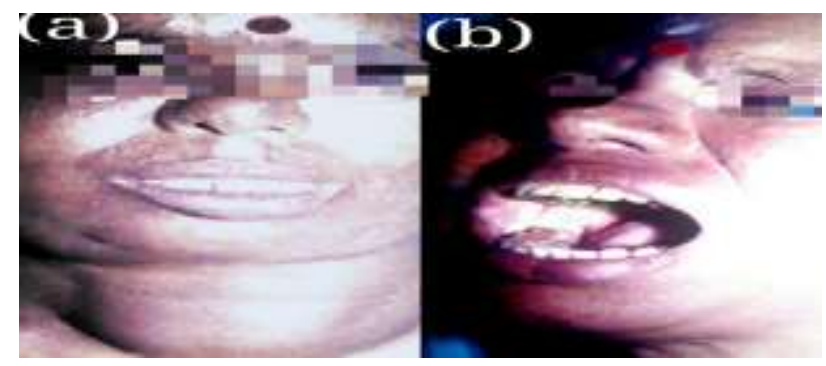

Figure 7: (Case no. 20) - Synchronous follicular carcinoma of thyroid, (a) and squamous cell carcinoma of the cheek (b) in a 52 year old woman.

Follicular carcinoma of the thyroid occurring synchronously with squamous cell carcinoma of the cheek (Case no. 20, Figure 7) parotid adenocarcinoma presenting synchronously with soft tissue sarcoma (Case no. 21) and metachronously 7 years after radiotherapy for supraglottic squamous cell carcinoma, with facial nerve paralysis (case no. 22, Figure 8), are the first ones to be reported.
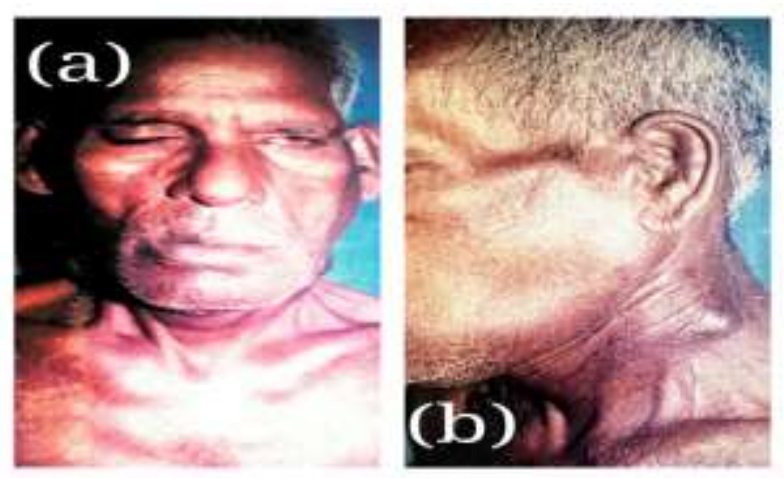

Figure 8: (Case no. 22) - Metachronous right parotid adenocarcinoma (with facial nerve palsy) seven years after radiotherapy for carcinoma supraglottis with left cervical node metastasis.

\section{Gastrointestinal malignancies}

Synchronous adenocarcinomas of the colon and the esophagus have been reported before. ${ }^{21}$ But metachronous squamous cell carcinoma of the esophagus with adenocarcinoma of colon has not been reported. Case no. 23, is a female with Squamous cell carcinoma of the esophagus presenting 2 years after successful treatment of adenocarcinoma of the colon. Studies linking these two malignancies point to alcoholism, smoking, dietary factors, cyclo-oxygenase 2 enzymes, Barret's esophagus as the common etiological factors.

Gastric malignancy following colonic adenocarcinoma is rare and is usually seen in HNPCC (hereditary nonpolyposis colorectal cancer). Gastric malignancies are the second most common extra colonic malignancies in HNPCC following endometrial carcinomas. ${ }^{22}$ These malignancies present in young age (mostly between 4048 years age) as is evident from our 42 year old patient (Case no. 24) who developed inoperable adenocarcinoma of the stomach 10 years following right hemi colectomy for carcinoma of the caecum.

Synchronous or metachronous carcinoma of the stomach and transitional cell carcinoma (TCC) of the urinary bladder are very rare. Only five cases have been reported in literature before. ${ }^{23-27}$ Case no. 25 in our study is probably the sixth reported case. The patient in our study is a 45 year old woman, a chronic tobacco user, who presented with synchronous advanced adenocarcinoma of the stomach and advanced TCC of the urinary bladder, and succumbed to the disease. As per Chaudhuri et al tobacco may be a common risk factor for both the malignancies in this patient. ${ }^{23}$

Familial cases of synchronous pancreatic adenocarcinoma and malignant melanoma have been observed in the familial atypical multiple mole melanoma syndrome (FAMMM), due to mutations in the CDKN2A gene. Pancreatic malignancy in these patients occur at a younger age, associated with other malignancies. ${ }^{28} \mathrm{We}$ 
report a 39 year old patient (Case no. 26), who presented with synchronous periampullary pancreatic adenocarcinoma and nodular melanoma with cerebral metastases and hemiplegia. There was no family history of melanoma or pancreatic malignancy.

\section{Lymphoreticular malignancies}

Case no. 27 , is a 75 year old woman who presented with small bowel non-Hodgkin's lymphoma (NHL), 3 years following surgery and chemotherapy (Cisplatin) for fallopian tube adenocarcinoma; and case no. 28, with synchronous squamous cell carcinoma of lung and multiple myeloma are the first cases to be reported. We also report the first case of NHL occurring 10 years after Radical nephrectomy for renal cell carcinoma (RCC), Case no. 29. Patients with NHL are at increased risk of RCC but not vice versa. ${ }^{29}$

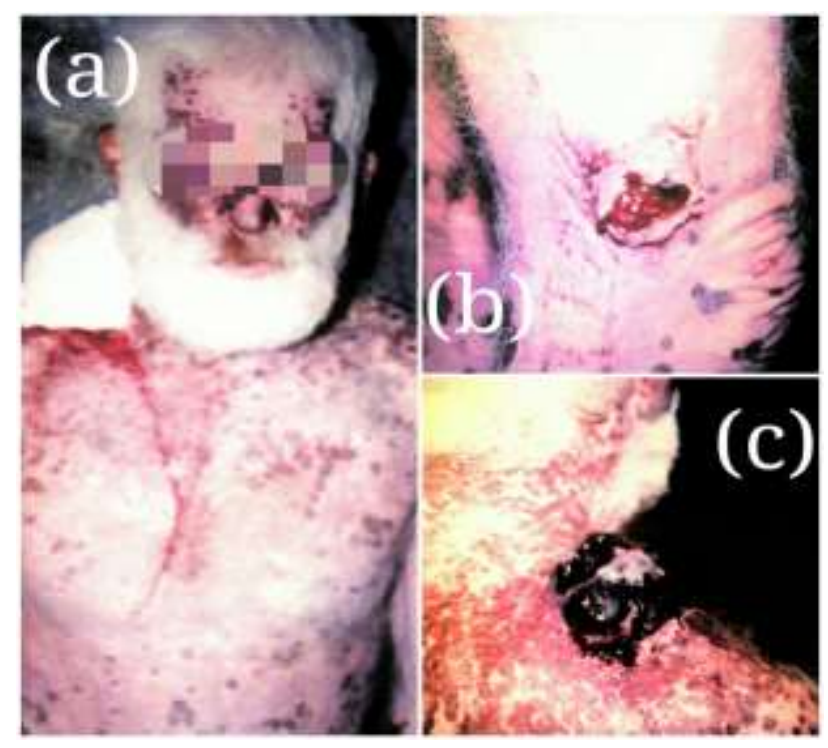

Figure 9: (Case no. 30)- (a) Synchronous squamous cell carcinoma of the thigh (b) and malignant melanoma of right side of the neck (c) in a patient with Oculocutaneous albinism.

Carcinoma esophagus developing after radiotherapy for Hodgkin's lymphoma is rare. It has been reported even 30 years following radiotherapy for Hodgkin's lymphoma. ${ }^{30}$ The Case no. 30 developed squamous cell carcinoma 14 years after radiotherapy for Hodgkin's lymphoma. The long duration and the absence of other risk factors point to prior radiation exposure as the etiology for esophageal malignancy.

\section{Cutaneous malignancies}

Only 27 cases of malignant melanoma have been reported in patients with Oculocutaneous Albinism. ${ }^{31}$ These patients develop amelanotic melanomas as they already have defective melanin pigmentation. Squamous cell carcinoma is also reported and it runs a more aggressive course, with high chance of recurrence in these patients.
But synchronous squamous cell carcinoma and pigmented malignant melanoma has not been reported in literature. ${ }^{31}$ The case no. 31, in the present study (Figure 9) is a known case of Oculocutaneous albinism, with synchronous melanoma of the right side of the neck and squamous cell carcinoma of the thigh. Both the lesions were advanced at presentation. Only palliative treatment was offered.

Xeroderma pigmentosa with both basal cell carcinoma and squamous cell carcinoma are rare with less than 10 such cases reported in literature. ${ }^{33,34}$ The case no. 32, in our study is a 23 years old female, a known case of Xeroderma pigmentosa, who presented with basal cell carcinoma of the inner canthus of left eye which was excised. Three years later she developed squamous cell carcinoma of the left lower eyelid (Figure 10).

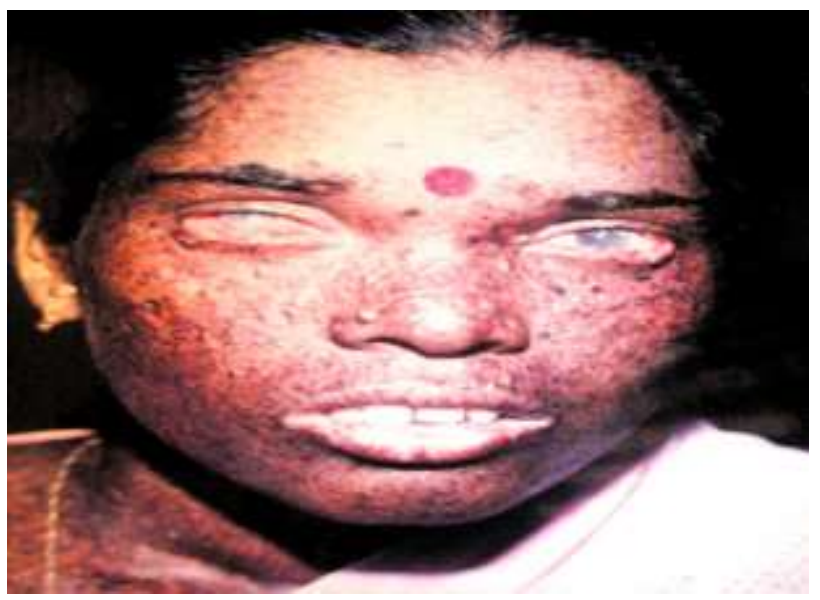

Figure 10: (Case no. 32)- Left lower eyelid Squamous cell carcinoma which appeared 3 years after surgical excision of Basal cell carcinoma of the inner canthus of same eye, in a 23 year old Xeroderma Pigmentosa patient.

The limitation of this study was, since the study includes retrospective cases, the patients could not be traced for gathering finer details. As the survival following second malignancy is poor, follow up was not adequate. Chemotherapy and Radiotherapy induced second primaries have a long latent period and a long term follow up could not be done. Hence the real incidence of second malignancies may be more. Pediatric malignancies were not included in the study. Advanced laboratory investigations and genetic studies were not done due to limited resources.

\section{CONCLUSION}

The frequency of double malignancies in our study was $1.5 / 1000$. Double malignancies are most common in female reproductive tract, followed by head and neck malignancies. A predilection for younger age group was observed in gynaecological double malignancies and syndromic malignancies. Most double malignancies 
occur by chance alone. Synchronous malignancies in different organs carry worse prognosis than those that occur in the same organ, as the latter are resectable. Metachronous second malignancies occurring very late do not influence the outcome of the first cancer and the prognosis depends upon its stage at detection. Second malignancies have developed as late as 30 years after radiotherapy and this stresses the importance of regular surveillance in these patients. Whenever possible, preventive measures should be carried out against second malignancy in patients with cancers who are susceptible for multiple malignancies.

\section{Funding: No funding sources}

Conflict of interest: None declared

Ethical approval: The study was approved by the institutional ethics committee

\section{REFERENCES}

1. Andrea K, Lisa, Ethel B, Gilbert, Lois B. Secondary malignancies across the age spectrum Semin Radiation Oncol. 2010;20(1):10.

2. Androutsopoulos G. Synchronous primary endometrial and ovarian cancers. J Community Med Health Educ. 2013;22:3:e120.

3. Ayhan A, Yalçin OT, Tuncer ZS, Gürgan T, Küçükali T. Synchronous primary malignancies of the female genital tract. Eur J Obstet Gynecol Reprod Biol. 1992;16:45(1):63-6.

4. Srivastava K, Zahra F. Synchronous primary malignancy of ovary and cervix with different histopathology: a rare presentation. Internet $\mathbf{J}$ Gynecol Obstet. 2009;12(2):1-4.

5. Katke RD, Gadekar S, Pagare P. Department of obstetrics and gynecology, grant government medical college and sir J. J. group of hospitals, Mumbai, Maharashtra, India. A rare case of carcinoma of ovary with carcinoma of cervix. J Case Rep. 2014;4(1):217-20.

6. John DB, Engholm G, Kleinerman RA, Blettner M, Stovall M, Lisco H, et al. Radiation dose and second cancer risk in patients treated for cancer of the cervix. Radiat Res. 1988;116(1):3-55.

7. Lonardo AD, Venuti A, Marcante ML. Human papillomavirus in breast cancer. Breast Cancer Res Treat. 1992;21(2):95-100.

8. Khan NA, Castillo A, Koriyama C, Kijima Y, Umekita Y, Ohi Y, et al. Human papillomavirus detected in female breast carcinomas in Japan. Br $\mathbf{J}$ Cancer. 2008;99(3):408-14.

9. Widschwendter A, Brunhuber T, Wiedemair A, Holzner EM, Marth C. Detection of human papillomavirus DNA in breast cancer of patients with cervical cancer history. J Clin Virol. 2004;31(4):292-7.

10. Gillison ML, Shah KV. Chapter 9: role of mucosal human papillomavirus in non-genital cancers. J Natl Cancer Inst Monogr. 2003;(31):57-65.
11. Leibowttch M, Neill S, Pelisse M, Baracco M. The epithelial changes associated with squamous cell carcinoma of the vulva: a review of the clinical, histological and viral findings in 78 women. BJOG Int J Obstet Gynaecol. 1990;97(12):1135-9.

12. Capps E, Shiller SM, Cheek S, Oza U, Konduri K. Chest wall chondrosarcoma. Proc Bayl Univ Med Cent. 2009;22(4):362-5.

13. Petrucelli N, Daly MB, Feldman GL. BRCA1 and BRCA2 Hereditary Breast and Ovarian Cancer. University of Washington, Seattle. 1993. 2016.

14. Băltătescu GI, Așchie M, Sârbu V. Synchronous ovarian dysgerminoma and breast carcinoma in a patient with positive immunostain of BRCA1. Chir Buchar Rom 1990. 2013;108(2):259-63.

15. Wolff EF, Martel M, Gwin K, Lannin D. Synchronous primary breast and ovarian cancer with ovarian cancer metastases to a breast sentinel lymph node. Breast J. 2009;15(2):203-5.

16. Jain KS, Sikora AG, Baxi SS, Morris LGT. Synchronous cancers in patients with head and neck cancer: risks in the era of human papillomavirusassociated oropharyngeal cancer. Cancer. 2013;119(10):1832-7.

17. Slaughter DP, Southwick HW, Smejkal W. Field cancerization in oral stratified squamous epithelium; clinical implications of multicentric origin. Cancer. 1953;6(5):963-8.

18. Krishnatreya M, Rahman T, Kataki AC, Das A, Das AK, Lahkar K. Synchronous primary cancers of the head and neck region and upper aero digestive tract: defining high-risk patients. Indian $\mathbf{J}$ Cancer. 2013;50(4):322-6.

19. Lakshmi CR, Rao MS, Bhavana SM, Sathish S. Primary squamous cell carcinoma of lung leading to metastatic jaw tumor. Case Rep Pulmonol Case Rep Pulmonol. 2014;2014:e392616.

20. Şule A, Beyhan D. An unusual case of bronchogenic carcinoma and oral cavity cancer: Metastatic oral cavity disease or a second primary tumor. Turk Respir J. 2000;1(1):75-8.

21. Gupta A, Chauhan B, Rangarajan V, Desai S, Noronha V, Prabhash K. Oesophageal carcinoma presenting with a synchronous asymptomatic colon carcinoma. Indian $\mathbf{J}$ Med Paediatr Oncol Off $\mathbf{J}$ Indian Soc Med Paediatr Oncol. 2013;34(2):117-20.

22. Park YJ, Shin KH, Park JG. Risk of gastric cancer in hereditary nonpolyposis colorectal cancer in Korea. Clin Cancer Res Off J Am Assoc Cancer Res. 2000;6(8):2994-8.

23. Chaudhuri T, Jain M, Mondal D, Rastogi N. Synchronous papillary urothelial carcinoma of urinary bladder and adenocarcinoma of stomach in a middle-aged man: An extremely rare association with therapeutic dilemma. Clin Cancer Investig J. 2013;2(2):156.

24. Ersoy GFA. Synchronous carcinomas of stomach and bladder together with AA amyloidosis (Case Report). Nephrol Carlton Vic. 2006;11(2):120-3. 
25. Yamasaki M, Kitamura S, Higuchi M. Case of synchronous quadruple cancer esophageal melanoma, gastric cancer, colonic cancer and bladder cancer. Gan No Rinsho Jpn J Cancer Clin. 1969;15(5):501-7.

26. Shikuwa S, Itoh M, Sekine I, Fujii H, Kitara M, Kobayasi M. A autopsy case of synchronous triple cancers including gastric cancer, early urinary bladder cancer and malignant pleural mesothelioma with metastatic malignant mesothelioma of the stomach. Nihon Shokakibyo Gakkai Zasshi Jpn J Gastro-Enterol. 1991;88(12):2871-6.

27. Ishiura $\mathrm{Y}$, Yamamoto $\mathrm{H}$, Ishida $\mathrm{Y}$, Yokawa $\mathrm{S}$, Fukushima W. A case of synchronous triple cancer involving lung, stomach and bladder, responding to combination chemotherapy of S-1 and Cisplatin. Gan Kagaku Ryoho. 2008;(35):1395-7.

28. Lynch HT, Brand RE, Hogg D, Deters CA, Fusaro RM, Lynch JF, et al. Phenotypic variation in eight extended CDKN2A germline mutation familial atypical multiple mole melanoma-pancreatic carcinoma-prone families. Cancer. 2002;94(1):8496.

29. Lossos C, Ferrell A, Duncan R, Lossos IS. Association between non-Hodgkin lymphoma and renal cell carcinoma. Leuk Lymphoma. 2011;52(12):2254-61.

30. Micke O, Schäfer U, Glashörster M, Prott FJ, Willich N. Radiation-induced esophageal carcinoma 30 years after mediastinal irradiation: Case Report and Review of the Literature. Jpn J Clin Oncol. 1999;29(3):164-70.

31. Streutker CJ, McCready D, Jimbow K, From L. Malignant melanoma in a patient with oculocutaneous albinism. J Cutan Med Surg. 2000;4(3):149-52.

32. Lekalakala PT, Khammissa RAG, Kramer B, Yusuf OA, Lemmer J, Feller L, et al. Oculocutaneous albinism and squamous cell carcinoma of the skin of the head and neck in sub-Saharan Africa, Oculocutaneous albinism and squamous cell carcinoma of the skin of the head and neck in subSaharan Africa. J Skin Cancer J Skin Cancer. 2015;2015:e167847.

33. Mohanty P, Mohanty L, Devi BP. Multiple cutaneous malignancies in xeroderma pigmentosum. Indian J Dermatol Venereol Leprol. 2001;67(2):96.

34. Grampurohit V, Rao R, Dinesh U. Multiple cutaneous malignancies in a patient of xeroderma pigmentosum. J Cancer Res Ther. 2011;7(2):205.

Cite this article as: Joseph SC, Darlington CD, Anitha GFS. A retrospective and prospective study of double malignancies in a tertiary care hospital in south India - a ten years' experience. Int Surg J 2016;3:674-82. 